\title{
Pengaruh Faktor Internal dan Eksternal Perusahaan Terhadap Audit Report Lag (Arl) Pada Perusahaan Bumn yang Tercatat di Bursa Efek Indonesia

\author{
Sigit Handoyo"
} \\ Dwiayu Fatmasari**
}

\begin{abstract}
This research aims to test the influence of internal and external factors of the company towards audit report lag (ARL). Variables measured in this study are the net profits, solvency, size of the company, the reputation, the auditor's opinion, and the audit fee. The study was done by using a purposive sampling method by taking the company's annual report on STATE-OWNED ENTERPRISES (BUMN) listed on the Indonesia stock exchange. Total company met the criteria as samples were 14 companies during the years 2009 to 2011 . In this research, hypothesis testing was using multiple regression analysis. The results of this research show that the variable net profits, solvency, the size of the company and the auditor's reputation do not have a significant influence toward the audit report lag, whereas the variable auditor's opinions and audit fee have a significant influence toward the audit report lag.
\end{abstract}

Keywords: Net income, solvency, size of the company, reputation of the auditor, auditors's opinion, audit fee, and audit report lag

\section{Pendahuluan}

Laporan keuangan merupakan salah satu cara bagi investor dalam memantau kinerja perusahaan go public. Perusahaan-perusahaan go public di indonesia mengalami kemajuan yang pesat. Perkembangan ini berdampak pada peningkatan permintaan akan audit laporan keuangan (Rachmawati, 2008). Audit atas laporan keuangan merupakan salah satu bentuk jasa atestasi yang dilakukan auditor. Auditor akan menerbitkan laporan tertulis yang berisi pernyataan pendapat

- Dosen Fakultas Ekonomi UII

** Alumni Fakultas Ekonomi UII 
apakah laporan keuangan yang dikeluarkan perusahaan telah disusun sesuai dengan prinsip-prinsip akuntansi yang berlaku umum.

Berdasarkan peraturan Badan Pengawas Pasar Modal (BAPEPAM) dengan Kep-36/PM/2003 dan BEJ dengan Kep-306/BEJ/07-2004 yang menyebutkan bahwa penyajian laporan keuangan untuk perusahaan yang go public diwajibkan menyampaikan laporan keuangan yang disusun sesuai dengan Standar Akuntansi Keuangan (SAK) dan telah diaudit oleh akuntan publik.

Carslaw dan Kaplan (1991), Rachmawati (2008) dalam Novice dan Budi (2010) menyatakan bahwa perusahaan yang mengalami rugi cendrung memerlukan proses pengauditan yang lebih lama. Oleh karena itu, maka akan terjadi pula keterlambatan dalam menyampaikan hal tersebut kepada publik. Ashton (1989) menyatakan ketepatan waktu pelaporan keuangan merupakan elemen pokok bagi catatan laporan keuangan yang memadai. Informasi yang diberikan didalam laporan keuangan harus bersifat baru. Berdasarkan PSAK no.1 tentang penyajian laporan keuangan paragraf 43 , jika terdapat penundaan yang tidak semestinya dalam pelaporan maka informasi yang dihasilkan akan kehilangan relevansinya.

Sejak tanggal 30 september 2003, BAPEPAM mengeluarkan lampiran surat keputusan ketua BAPEPAM Nomor : Kep-36/PM/2003 yang menyatakan bahwa laporan keuangan disertai dengan laporan akuntan dengan pendapat yang lazim harus disampaikan kepada BAPEPAM selambat-lambatnya pada akhir bulan ketiga (90 hari) setelah tanggal laporan keuangan tahunan. Jangka waktu antara tanggal tahun buku perusahaan berakhir sampai dengan tanggal laporan audit seiesai dilakukan disebut Audit Report lag atau biasa disebut dengan audit delay (Petronila, 2007).

Penelitian ini termotivasi untuk menguji faktor-faktor internal dan eksternal perusahaan terhadap audit report lag pada perusahaan Badan Usaha Milik Negara (BUMN). Tujuan yang hendak dicapai dalam penelitian ini adalah untuk menemukan bukti empiris tentang pengaruh faktor internal perusahaan laba bersih perusahaan, solvabilitas, ukuran perusahaan dan faktor eksternal berupa opini auditor, reputasi auditor, besarnya audit fee terhadap audit report lag.

\section{Kajian Pustaka}

\section{Audit Report Lag}

Terdapat delapan tahap dalam pelaksanaan audit (phases of an audit) yaitu:

a. Menerima/melanjutkan klien.

Standar profesional mensyaratkan kantor akuntan publik untuk menetapkan kebijakan dan prosedur untuk menentukan apakah akan menerima klien baru dan mempertahankan klien yang telah ada. Standar 
pengendalian mutu menyediakan petunjuk profesional bekenaan dengan keputusan untuk menerima dan melanjutkan klien dan perikatan. Menerima dan melanjutkan klien audit melibatkan elemen-elemen penting mengenai pemahaman bisnis dan industri, materialitas, risiko audit, dan pertimbangan jasa bernilai tambah.

b. Praperencanaan

Secara umum terdapat tiga aktivitas praperencanaan, yaitu:

a) Pemutakhiran pemahaman tentang klien atau mendapatkan pemahaman yang mendalam tentang klien baru dan lingkungannya.

b) Menentukan kebutuhan tim audit.

c) Memastikan indepedensi tim audit dan kantor akuntan.

Karena pemahaman terhadap klien dan lingkungannya digunakan untuk menentukan risiko kesalahan saji material dan untuk menetapkan lingkup audit, maka auditor harus melakukan prosedur penentuan risiko untuk mendukung pemahaman tersebut.

c. Menetapkan materialitas dan menentukan risiko

Tim audit harus membuat penentuan awal mengenai risiko bisnis klien dan menentukan materialitas. Tim audit tergantung pada pertimbangan ini sehingga kemudian menentukan risiko yang berhubungan dengan kemungkinan adanya kesalahan saji material dalam laporan keuangan.

d. Merencanakan audit

Perencanaan yang tepat adalah penting untuk memastikan bahwa audit dilaksanakan dengan cara yang efektif dan efisien.

e. Mempertimbangkan dan mengaudit pengendalian internal

Pada saat memperoleh pemahaman mengenai entitas dan lingkungannya, auditor seharusnya memperoleh pemahaman mengenai pengendalian internal.

f. Audit proses bisnis dan akun terkait

Auditor biasanya menentukan risiko salah saji materi dengan memeriksa proses bisnis entitas atau siklus akuntansi. Auditor kemudian menentukan prosedur audit yang diperlukan untuk mengurangi risiko salah saji material ke tingkat yang lebih rendah bagi akun-akun laporan keuangan yang terpengaruh oleh proses bisnis tertentu.

g. Menyelesaikan audit

Setelah auditor selesai menguji saldo akun, kecukupan bukti yang dikumpulkan perlu dievaluasi. Auditor harus mendapatkan bukti kompeten yang cukup untuk mencapai dan membenarkan kesimpulan mengenai kewajaran laporan keuangan.

h. Mengevaluasi hasil dan menerbitkan laporan 
Fase akhir dari proses audit adalah memilih laporan audit yang tepat unutk diterbitkan. Tujuan auditor pada saat menyelesaikan audit adalah memastikan bahwa risiko salah saji material dikurangi sampai tingkat yang dapat diterima sehingga laporan keuangan secara keseluruhan kemungkinan besar telah disajikan secara wajar. Pada standar pelaporan keempat mengharuskan laporan audit berrisi suatu petunjuk yang jelas tentang sifat pekerjaan auditor serta tingkat tanggung jawab yang ditanggungnya atas laporan keuangan. Laporan audit merupakan hal yang penting dalam penugasan audit, karena laporan audit berfungsi sebagai alat komunikasi antara auditor dengan pengguna. Opini yang dikeluarkan oleh auditor atas pemeriksaan laporan keuangan perusahaan, merupakan suatu pertimbangan penting bagi para investor dalam mengambil keputusan. Terdapat lima opini yang diberikan oleh auditor berdasarkan hasil pengauditan atas laporan keuangan kliennya yaitu unqualified opinion, unqualified opinion with explanation language, qualified opinion, adverse opinion, and disclaimer opinion.

Dengan adanya tahapan-tahapan audit (phases of an audit) yang sesuai dengan standar pekerjaan lapangan pertama dan ketiga yang menyatakan bahwa audit harus dilaksanakan dengan perencanaan yang matang dan pengumpulan alatalat pembuktian yang cukup memadai, maka penyelesaian audit pada suatu perusahaan akan membutuhkan waktu yang relatif lama, akibatnya akuntan publik dapat menunda untuk mempublikasikan laporan audit atau laporan keuangan auditannya.. Dalam banyak penelitian hal tersebut dinamakan audit delay / audit report lag.

Menurut Imam Subekti (2005), audit report lag/audit delay adalah periode waktu antara akhir tahun fiskal dan tanggal laporan audit perusahaan. Oleh karena itu, semakin lama auditor dalam meyelesaikan pekerjaan auditnya maka semakin panjang audit delay.

Perencanaan audit yang memadai ini akan mempengaruhi kinerja dari auditor. Pemenuhan standar audit dapat menyebabkan lamanya penyelesaian laporan audit, tetapi juga dapat meningkatkan kualitas audit tersebut. Pendapat Ashton (1989) mengatakan bahwa proses audit sangat memerlukan waktu yang berakibat adanya audit delay yang nantinya akan sangat berpengaruh pada ketepatan waktu pelaporan keuangan.

\section{Pengembangan hipotesis}

a. Laba bersih

Dalam penelitian Carslaw dan Kaplan (1991) perusahaan yang melaporkan laba yang tinggi akan berharap laporan keuangan auditan dapat diselesaikan 
secépatnnya, sehingga good news tersebut dapat segera disampaikan kepada para investor dan pihak yang berkepentingan. Namun jika perusahaan melaporkan kerugian kemungkinan perusahaan akan meminta auditor untuk mengatur waktu auditnya lebih lama dibandingkan biasanya karena tidak ingin menyampaikan bad news kepada publik.

$\mathbf{H}_{\mathbf{a}} \mathbf{l}$ :laba bersih yang dilaporkan berpengaruh terhadap audit report lag

b. Solvabilitas

Menurut Almilia (2006), Solvabilitas adalah kemampuan perusahaan untuk membayar semua hutangnya (baik hutang jangka pendek maupun hutang jangka panjang) dari harta perusahaan tersebut. Terdapat dua rasio yang umum digunakan untuk mengukur rasio solvabilitas yaitu Total Debt to Totál Assets dan Times Interest Earned. Proporsi yang besar dari hutang terhadap total aktiva akan meningkatkan kecenderungan kerugian dan dapat meningkatkan kehatia-hatian auditor terhadap laporan keuangan yang akan diaudit. Oleh karena itu, Solvabilitas yang buruk merupakan bad news bagi perusahaan sehingga perusahaan cenderung berusaha untuk "memoles" telebih dahulu atau melakukan mismanagement dan fraud sebelum laporan keuangan disajikan.

Penelitian Novice dan Budi hartono (2010) menemukan adanya pengaruh solvabilitas terhadap audit report lag. Tetapi Almilia (2006) berpendapat bahwa solvabilitas tidak berpengaruh terhadap audit report lag.

\section{$\mathbf{H}_{\mathbf{a}} \mathbf{2}$ : Solvabilitas berpengaruh terhadap audit report lag}

c. Ukuran perusahaan

Ukuran perusahaan merupakan salah satu faktor yang berpengaruh terhadap audit report lag. Ukuran perusahaan dapat menunjukkan seberapa besar informasi yang terdapat di dalamnya, sekaligus mencerminkan kesadaran dari pihak manajemen mengenai pentingnya informasi, baik bagi pihak eksternal perusahaan maupun pihak internal perusahaan. perusahaan berskala besar cendrung lebih cepat menyampaikan laporan keuangan-yang telah di audit dibandingkan dengan perusahaan kecil. Perusahaan besar umumnya dimonitor oleh investor, pengawas permodalan, dan pemerintah sehingga terdapat kecendrungan mengurangi audit report lag (Novice dan Budi Hartono, 2010).

Novice dan Budi Hartono (2010) berpendapat bahwa ukuran perusahaan tidak berpengaruh terhadap audit reprot lag, tetapi Subekti dan Wulandari (2004) menemukan bahwa ukuran perusahaan berpengaruh terhadap audit repot lag. Demikian juga Almilia (2006) yang berpendapat sama dengan penelitian tersebut.

$\mathbf{H}_{\mathbf{a}} \mathbf{3}$ :Ukuran perusahaan berpengaruh terhadap audit report lag.

d. Reputasi auditor 
Reputasi auditor yang dimaksudkan disini adalah kantor akuntan publik yang berada di indonesia yang bisa dikategorikan the big four. Karena kantor akuntan publik tersebut dianggap dapat melaksanakan audit secara lebih efisien dan memilki auditor yang memilki kemampuan untuk menyelesaikan audit tepat waktu.

$\mathbf{H}_{\mathbf{a}} 4 \quad$ : Reputasi auditor berpenganuh terhadap audit report lag

e. Opini Auditor

Opini auditor digolongkan menjadi lima, yaitu opini wajar tanpa pengecualian (unqualified opinon), opini wajar tanpa pengecualian dengan bahasa penjelasan (unqualified opinion with explanatory language), opini wajar dengan pengecualian (qualified opinion), opini tidak wajar (adverse opinion), tiidak memberikan opini (disclaimer). Penelitian Subekti dan Wulandari (2004) menemukan bahwa opini auditor berpengaruh terhadap audit report lag.

\section{$\mathrm{H}_{\mathrm{a}} 5$ : Opini auditor berpengaruh terhadap audit report lag}

\section{f. Audit fee}

Perusahaan yang memiliki tingkat profitabilitas yang tinggi akan mempunyai alokasi dana yang besar untuk membayar audit fee atas pekerjaan audit KAP. KAP besar cendrung dapat melakukan pekerjaan audit yang lebih cepat dibandingkan KAP kecil. Hal tersebut akan dipengaruhi oleh audit fee yang harus dibayarkan oleh perusahaan kepada KAP. Untuk memakai jasa KAP besar akan membutuhkan biaya yang relatif besar.

\section{$\mathbf{H}_{\mathrm{a}} 6 \quad$ : Audit fee berpengaruh terhadap audit report lag.}

\section{Metode penelitian}

\section{Pemilihan sampel dan pengumpulan data}

Obyek penelitian yang digunakan adalah perusahan BUMN yang terdaftar di Bursa Efek Indonesia (BEI). Pemilihan sampel menggunakan metode purposive sampling yang dipilih berdasarkan kriteria terdaftar di BEI dari tahun 2009-2011, menyampaikan laporan keuangan dan laporan tahunan, laporan keuangan berakahir 31 Desember, menerbitkan laporan auditor independen yang memuat pemberian pendapat akuntan publik. Jumlah sampel yang memenuhi kriteria adalah 14 perusahaan, jumlah data yang digunakan dalam penelitian ini adalah sebanyak 42 data penelitian. Jenis data yang digunakan adalah data dokumenter, sedangkan sumber data dalam penelitian ini adalah data sekunder berbentuk laporan keuangan, laporan tahunan, laporan ringkasan perusahaan dan tanggal laporan auditor independen. Semua data tersebut dapat diakses langsung dari www.idx.co.id atau diperoleh di pojok Bursa Efek Jakarta Universitas Islam 
Indonesia, Pusat Referensi Pasar Modal dan indonesaian Capital Market Directory (ICMD)

\section{Variabel yang digunakan}

Dalam penelitian ini variabel yang digunakan terdiri dari variabel dependen dan variabel independen. Variabel dependen dalam penelitian ini adalah audit report lag. Sedangkan variabel independen dalam penelitian ini adalah laba bersih, solvabilitas, ukuran perusahaan, reputasi auditor, opini auditor, dan audit fee.

\section{a. Audit report lag}

Audit report lag yang dimaksud adalah periode waktu antara akhir tahun fiskal dan tanggal laporan audit perusahaan. Variabel audit report lag diukur secara kuantitatif dari tanggal penutupan buku perusahaan hingga

I diterbitkannya laporan audit.

b. Labạ bersih

Variabel laba bersih perusahaan diukur sebesar laba bersih yang dicantumkan dalam laporan keuangan kemudian dilogaritmakan! Satuan laba bersih yang digunakan adalah jutaan rupiah.

c. Solvabilitas

Variabel solvabilitas diproksikan melalui besarnya rasio total debt to total assets yang diukur dari total kewajiban dibagi dengan total aktiva.

d. Ukuran perusahaan

Ukuran perusahaan dalam penelitian ini diukur sebesar total asset yang dicantumkan dalam laporan keuangan kemudian dilogaritmakan! Satuan total asset yang digunakan adalah jutaan rupiah.

e. Reputasi auditor

l Variabel reputasi auditor diproksikan dengan variabel dummy. Jika perusahaan menggunakan KAP lokal yang berafiliasi dengan KAP the big four maka diberi nilai 0 , jika tidak diberi nilai 1 .

\section{f. Opini auditor}

Variabel opini auditor diproksikan dengan variabel dummy. Jika perusahaan mendapat opini wajar tanpa pengecualian maka diberi nilai 0 . Selain opini wajar tanpa pengecualian diberi nilai 1.

g. Audit fee

Variabel audit fee diukur sebesar jumlah uang yang dibayarkan klien terhadap KAP kemudian dilogaritmakan.

\section{Metode analisis}

Mengingat bahwa skala pengukuran variabel dependen adalah rasio dan variabel independen menggunakan skala rasio dan nominal maka penelitian ini menggunakan model regresi sebagai berikut: 


$$
\begin{aligned}
\text { ARL }= & \beta_{0}+\beta_{1} \text { (LOGNETINC) }+\beta_{2}(\text { SOLV })+\beta_{3} \text { (LOGTOTASSET) }+ \\
& \beta_{4} \text { (AUD) }+\beta_{5}(\text { OPIN })+\beta_{6} \text { (LOGFE) }
\end{aligned}
$$

\begin{tabular}{|c|c|}
\hline $\begin{array}{l}\mathrm{ARL} \\
\mathrm{B}_{0}\end{array}$ & $\begin{array}{l}=\text { lamanya waktu penyelesaian audit } \\
=\text { konstanta }\end{array}$ \\
\hline LOGNETINC & $\begin{aligned}= & \text { laba bersih (total laba bersih ya } \\
& \text { dilogaritmakan) }\end{aligned}$ \\
\hline LOGTOTASSET & $=\begin{array}{l}\text { Ukuran Perusahaan (total asset ya } \\
\text { dilogaritmakan) }\end{array}$ \\
\hline SOLV & $\begin{array}{c}=\begin{array}{l}\text { tingkat Solvabilitas (total kewajiban/tot } \\
\text { asset) }\end{array}\end{array}$ \\
\hline AUD & $\begin{aligned}= & \text { reputasi auditor (dummy; } 0=\text { non the } b \\
& \text { four, } 1 \text { the big four) }\end{aligned}$ \\
\hline OPIN & $\begin{array}{l}=\text { jenis pendapat akuntan publik (dummy; } \\
0=\text { non unqualified opinion, } 1=\text { unqualified } \\
\text { opinion) }\end{array}$ \\
\hline LOGFEE & $\begin{aligned}= & \text { audit fee yang dikeluarkan perusahaan (to } \\
& \text { audit fee yang dilogaitmakan) }\end{aligned}$ \\
\hline
\end{tabular}

$\because$ Keterangan :

\section{Hasil penelitian}

\section{Analisis deskriptif}

Tabel 1

Descriptive Statistics

\begin{tabular}{|l|r|r|r|r|r|}
\hline & N & Minimum & Maximum & Mean & $\begin{array}{c}\text { Std. } \\
\text { Deviation }\end{array}$ \\
\hline Laba & 42 & 4.80 & 7.18 & 6.0450 & .65211 \\
Solvabilitas & 42 & .18 & .92 & .5584 & .25681 \\
Size & 42 & 6.19 & 8.67 & 7.2333 & .62183 \\
REPUTASI (X4) & 42 & .00 & 1.00 & .6667 & .47712 \\
OPINI & 42 & .00 & 1.00 & .5000 & .50606 \\
AUDIT FEE & 42 & 2.39 & 4.70 & 3.2020 & .52618 \\
ARL & 42 & 51.00 & 120.00 & 77.0476 & 13.63631 \\
Valid N (listwise) & 42 & & & & \\
\hline
\end{tabular}

Sumber : lampiran 4 halaman 58 
5. Pengujian hipotesis

\begin{tabular}{|c|c|c|c|c|c|c|c|c|}
\hline \multirow[b]{2}{*}{ Mode } & & \multicolumn{2}{|c|}{$\begin{array}{l}\text { Unstandardized } \\
\text { Coefficients }\end{array}$} & \multirow{2}{*}{\begin{tabular}{|c}
$\begin{array}{c}\text { Standardize } \\
d \\
\text { Coefficients }\end{array}$ \\
Beta \\
\end{tabular}} & \multirow[b]{2}{*}{$t$} & \multirow[b]{2}{*}{ Sig. } & \multicolumn{2}{|c|}{$\begin{array}{l}\text { Collinearity } \\
\text { Statiștics }\end{array}$} \\
\hline & & B & $\begin{array}{l}\text { Std. } \\
\text { Error }\end{array}$ & & & & Tolerance & VIF \\
\hline \multirow[t]{7}{*}{1} & (Constant) & 88.379 & 26.833 & & 3.294 & .002 & & \\
\hline & Laba & -7.887 & 6.627 & -.377 & -1.190 & .242 & .174 & 5.742 \\
\hline & Solvabilitas & 14.592 & 11.939 & .275 & 1.222 & .230 & .346 & 2.890 \\
\hline & Size & -4.600 & 7.531 & -.210 & -.611 & .545 & .148 & 6.742 \\
\hline & $\begin{array}{l}\text { REPUTASI } \\
\text { (X4) }\end{array}$ & 2.965 & 5.444 & .104 & .545 & .589 & .482 & 2.074 \\
\hline & OPINI & -10.144 & 3.624 & -.376 & -2.799 & .008 & .967 & 1.034 \\
\hline & AUDIT FEE & 20.164 & 6.401 & .778 & 3.150 & .003 & . .287 & 3.488 \\
\hline
\end{tabular}

a. Dependent Variable: ARL

Sumber: lampiran 8 halaman 60

\section{Pembahasan hasil penelitian}

Hasil pengolahan data disajikan secara lengkap di lampiran. Berdasarkan statistik deskriptif dapat diketahui bahwa rata-rata audit report lag adalah 77.05 hari (77 hari) dengan standar deviasi 13,63 hari. Penelitan Novice dan Budi (2010) menúnjukan bahwa rata-rata audit report lag periode 2004-2008 adalah 70 hari.

Untuk memperoleh model prediksi (regresi) yang baik maka perlu dilakukan uji asumsi, hasil uji asumsi dapat dilihat dilampiran. Hasil uji asumsi yang dilakukan adalah sebagai berikut:

a. Nilai Variance Inflation Factor (VIF) pada semua variabel independen menunjukan angka $<10$, hal ini berarti tidak ada masalah multikolinearitas.

b. Nilai Durbin-Watson sebesar 1.375 menunjukan bahwa tidak terdapat masalah autokorelasi.

c. Berdasarkan plot dari studentized residual (sumbu Y) dengan standardized predicted value (sumbu $\mathrm{X}$ ) menunjukan tidak ada membentuk suatu pola tertentu yang teratur, ini berarti bahwa tidak terjadi heteroskedastisitas.

d. Berdasarkan normal probability plot menunjukan bahwa data menyebar di atas diagram dan mengikuti model regresi sehingga dapat data model regresi memenuhi asumsi normalitas. 
Hasil uji hipotesa secara simultan pada model regresi, dapat diketahui bahwa secara serentak variabel independen berpengaruh signifikan terhadap audit report lag. Hal ini dibuktikan dengan hasil statistik yaitu p-Value $(0.006)<$ alpha $(0.05)$

Variabel laba bersih perusahaan memiliki probabilitas signifikansi sebesar 0.242 . Hal ini menunjukan bahwa besar laba yang didapatkan perusahaan tidak memiliki pengaruh yang signifikan terhadap audit report lag sehingga $\mathrm{HO}_{1}$ gagal ditolak. Wiwik (2006) menyatakan bahwa laba/rugi mempunyai pengaruh yang signifikan terhadap audit delay. Perusahaan yang melaporkan rugi akan membutuhkan waktu audit yang lebih panjang dibandingkan perusahaan yang melaporkan laba.

Variabel solvabilitas memiliki probabilitas signifikansi sebesar 0.230 . Hal ini menunjukan bahwa ukuran perusahaan tidak memilki pengaruh yang signifian terhadap audit report lag sehingga $\mathrm{HO}_{2}$ gagal ditolak. Hasil penelitian ini tidak konsisten dengan penelitian Novice dan Budi (2010) dan penelitian Rachmawati (2008) yang menyatakan bahwa solvabilitas berpengaruh terhadap audit report lag. Tidak berpengaruhnya solvabilitas mungkin dikarenakan dalam pelaksanaan audit, auditor akan tetap berhati-hati dan cermat dalam melaksanakan audit terkait dengan besar kewajiban yang dimiliki perusahaan.

Variabel ukuran perusahaan memiliki probabilitas signifikansi sebesar 0.545. Hal ini menunjukan bahwa ukuran perusahaan pada perusahaan BUMN tidak mempunyai pengaruh yang signifikan terhadap audit report lag sehingga $\mathrm{HO}_{3}$ gagal ditolak. Hasil penelitian ini sejalan dengan penelitian Novice dan Budi (2010) dan Supriyati dan Rolinda (2007) namun tidak konsisten dengan Subekti dan Widiyanti (2004) dan Petronila (2007). Tidak berpengaruhnya ukuran perusahaan mungkin disebabkan semua perusahaan selalu diawasi oleh para investor, kreditor, regulator dan berbagai pihak lain sehingga dituntut untuk segera menyelesaikan pelaksanaan audit laporan keuangan tahunan perusahaan.

Variabel reputasi auditor memiliki probabilitas signifikansi sebesar 0.589 . Hal ini menunjukan bahwa reputasi auditor tidak mempunyai pengaruh yang signifikan terhadap audit report lag dan $\mathrm{HO}_{4}$ gagal ditolak. Hasil penelitian ini konsisten dengan penelitian Wiwik (2006). Reputasi the big four auditor bukan merupakan jaminan untuk kecepatan penyelesaian audit. Dalam penelitian ini auditor kecil (non big four) dapat mengimbangi kecepatan auditor besar.

Variabel opini auditor memilki probabilitas signifikansi pada sebesar 0.008 . Hal ini menunjukan bahwa opini auditor mempunyai pengaruh yang signifikan terhadap audit report lag dan $\mathrm{H}_{5}$ ditolak. Hasil penelitian ini konsisten dengan penelitian Wiwik (2006) . Ketika opini auditor adalah selain unqualified dikeluarkan, maka sebelum opini tersebut dipublikasikan manajemen akan berusaha melakukan konsultasi dan negoisasi secara instensif dengan auditor 
sehingga memerlukan waktu yang relatif lama dan audit report lag akan menjadi lebih panjang

Variabel audit fee memiliki probabilitas signifikansi sebesar 0.003 . Hal ini menunjukan bahwa audit fee mempunyai pengaruh yang signifikan terhadap audit report lag dan $\mathrm{H}_{6}$ ditolak. Hal ini berarti semakin besar biaya yang dikeluarkan perusahaan akan mempercepat kinerja KAP untuk menyelasaikan audit.

\section{Penutup}

\section{Kesimpulan}

Penelitian ini dilakukan dengan tujuan untuk mengetahui apakah terdapat pengaruh antara variabel independen terhadap dependen dimana variabel independen berupa faktor internal perusahaan berupa laba bersih perusahaan, - solvabilitas serta ukuran perusahaan dan faktor eksternal perusahaan berupa reputasi auditor, opini auditor dan audt fee. Variabel dependennya adalah audit report lag. berdasarkan hasil analisis yang telah dilakukan pada bab sebelumnya dapat disimpulkan bahwa faktor internal perusahaan berupa laba bersih perusahaan, solvabilitas dan ukuran perusahaan tidak berpengaruh terhadap audit report lag pada perusahaan BUMN. Sedangkan sebagian faktor eksternal perusahaan berupa opini auditor dan audit fee memiliki pengaruh yang signifikan terhadap audit report lag pada perusahaan BUMN, tetapi reputasi auditor tidak memiliki pengaruh yang signifikan terhadap audit report lag pada perusahaan BUMN.

\section{Keterbatasan}

Penelitian ini memiliki beberapa keterbatasan terutama karena pembatasan variabel yang diteliti hanya sebanyak enam variabel. Beberapa faktor lain yang mungkin memiliki pengaruh terhadap audit report lag tidak dimasukan dalam penelitian ini. Seperti faktor luas audit yang dilakukan dan kompleksitas perusahaan yang di audit. Periode sampel yang digunakan dalam penelitian ini hanyá periode 2009-2011

\section{Saran}

Sehubungan dengan keterbatasan yang dijelaskan di atas, maka saran untuk penelitian selanjutnya dapat memperluas sampel dengan meneliti perusahaan yang tidak hanya terdaftar di BEI atau dengan kelompok industri yang berbeda. Mengembangkan variabel-variabel lainnya yang mempengaruhi audit report lag seperti luas audit yang dilakukan dan kompleksitas perusahaan yang di audit. Faktor-faktor lain yang dipilih dapat juga mengacu pada data primer selain data sekunder perusahaan seperti pengendalian internal perusahaan dan resiko audit yang dihadapi oleh auditor. 


\section{DAFTAR PUSTAKA}

Almilia, dan Lucas Setiady. 2006. Faktor-Faktor yang Mempengaruhi Penyelesaian Penyajian Laporan Keuangan pada Perusahaan yang Terdaftar di BEJ. Seminar nasional good Corporate Governance. November hlm 1-11

Asthon, R.H., P.R. Graul, and J.D.Newton,1989. Audit Delay and the Timeliness of Corporate Reporting, Contemporary Accounting Research, Spring 1989, pp. $657-673$.

Carslaw, Charles A.P.N. and Steven E. Kaplan, An Examination of Audit Delay: Further Evidence From New Zaeland, Accounting and Bussiness Research (22: 85), 1991. Pp. 21-32.

Novice, dan Budi hartono. 2010. Faktor-faktor yang Berpengaruh Terhadap Audit Report Lag. Jurnal bisnis dan akuntansi. Vol. 12, No. 2, Agustus 2010 Hlm 97- 106

Petronila, Thio Anastasia. 2007. Analisis Skala Perusahaan, Opini Audit, dan Umur Perusahaan atas Audit Report Lag. Akuntabilitas. Maret 2007. Hlm. 129-141

Rachmawati, Sistya. 2008. Pengaruh Internal dan Eksternal Terhadap Audit Report Lag dan Timeliness. Jurnal akuntansi dan keuangan. Vol.10 No.1. Mei. HIm $1-10$

Subekti, Imam dan Novi Wulandari W. 2004. Faktor-Faktor yang Mempengaruhi Audit Report Lag di Indonesia. Simposium nasional akuntansi VII denpasar - bali. 2 - 3 Desember hlm 991-1001

Supriyati dan Yuliasri Rolinda. 2007. Analisis Faktor-Faktor yang Mempengaruhi Audit Report Lag: Study Empiris pada Perusahaan Manufaktur dan Finansial di Indonesia. Ventura. Vol.10, No.3, Desember hlm. 109 - 125

Utami, Wiwik. 2006. Analisis Determinan Audit Delay kajian empiris di Bursa Efek Indonesia. Bulletin Penelitian. No. 60, tahun 2006. 